\title{
RELATIONSHIP BETWEEN ROOT GROWTH OF 'THOMPSON SEEDLESS' GRAPEVINES AND SOIL TEMPERATURE
}

\author{
Rodrigo Callejas R. ${ }^{*}$, Pablo Canales P. ${ }^{1}$, and Víctor García de Cortázar G. de C. ${ }^{1}$
}

\begin{abstract}
With the purpose of characterizing the growth of the root system of table grapes (Vitis vinifera L.) cv. Thompson Seedless and its relationship with soil temperature, research was carried out during the 2004-2005 growing season in vineyards in the Copiapó and Huasco Valleys. Four plants were chosen and rhizotrons were used to measure the growth of the root system. Measurements were performed once a week from September 2004 to September 2005 , estimating the intensity of root growth and its annual distribution in the ranges of 0 to 40,40 to 80 and 80 to 120 $\mathrm{cm}$ of soil depth. Temperature sensors were installed in four plants at 25, 50, 75 and $100 \mathrm{~cm}$ of soil depth, and the temperature was registered every $1 \mathrm{~h}$. The thermal diffusivity of the soil was calculated based on the annual mean temperature and annual thermal amplitude values. Root growth occurred throughout the year, presenting lower intensity in July (winter). Root systems presented different patterns in the distribution of growth intensity in the three soil depths, with variations in the order of five times in maximum annual growth intensity among sites. High thermal diffusivity in soils favored root growth.
\end{abstract}

Key words: roots, thermal diffusivity, tablegrape.

\section{INTRODUCTION}

Research into the architecture, rooting and mortality of roots requires special techniques. In this sense, the use of observation chambers, or rhizotrons, constitutes a nondestructive in situ method that allows addressing this task (van Noordwijk et al., 1985). Research into grapevine root systems has shown patterns that are dependent on age, cultivar, climate and environmental stress. Two growth peaks have been determined for roots of cv. Thompson Seedless (Ruiz, 2000), the first occurring between 3 to 10 weeks after budding and decreasing in intensity with berry growth (McArtney and Ferree, 1999). The spring growth peak has been related to superficial growth and abundant fine rootlets, with the intensity dependent on the level of reserves of the roots (Terence et al., 2002). The second peak, which is less intense than the first, occurs after harvesting the fruit.

The patterns of root growth can vary among different climatic regions, soil conditions, cultural practices or rootstock genotypes (Psarras et al., 2000), while changes in root morphology -characterized by differences in

${ }^{1}$ Universidad de Chile, Facultad de Ciencias Agronómicas, Casilla 1004, Santiago, Chile. "Corresponding author (rcalleja@uchile.cl). Received: 17 October 2008.

Accepted: 21 February 2009. root length, dry matter and rooting- are associated with changes in soil temperature (McMichael and Burke, 1998). It has been proposed that if all the factors that affect root development are in optimal conditions, soil temperature would be the main modifier of root growth.

Woodham and Alexander (1966) observed a direct relationship between root growth and the rise in soil temperature from 15 to $30^{\circ} \mathrm{C}$, and established that the optimal soil temperature for grapevines is close to $30^{\circ} \mathrm{C}$, which was corroborated subsequently by Kliewer (1975).

Although it is known that the periodicity of root system growth plays a fundamental role from the perspectives of ecology and fruit production, current information is scarce. There is special interest in the Copiapó and Huasco Valleys, Atacama Region, where the local thermal characteristics can induce behaviors different from those reported to date in other research. Given this, the present study was directed at characterizing root growth of 'Thompson Seedless' grape vines in the Atacama Region, Chile, and its relationship with soil temperature.

\section{MATERIALS AND METHODS}

The study was carried out during the 2004-2005 season in vineyards of cv. Thompson Seedless located in the Copiapó and Huasco Valleys (between $27^{\circ}$ and $28^{\circ} \mathrm{S}$, and $70^{\circ} \mathrm{W}$; 973-1223 m.a.s.1.), Atacama Region, Chile. 
The climatic grouping is desert highland, with an average annual precipitation of $27 \mathrm{~mm}$ (Novoa et al., 1989). The grapevines were cultivated using drip irrigation and were irrigated with approximately $12000 \mathrm{~m}^{3} \mathrm{ha}^{-1}$ year-1 $^{-1}$. The plants budded at the beginning of August, flowered by mid-September and were harvested beginning the second half of December.

Four observation chambers or rhizotrons (Table 1) were used to characterize root growth. The rhizotrons were placed over the row at $90 \mathrm{~cm}$ of the trunks of randomly selected representative plants at each site. The rhizotrons had observation windows of $1.2 \times 1.0 \mathrm{~m}$ ( $8 \mathrm{~mm}$ thick). The glass on the windows was divided into a grid with $2.5 \times 2.5 \mathrm{~cm}$ squares. The intersections of new roots were measured once a week using the grid, at soil depth ranges of 0 to 40,40 to 80 and 80 to $120 \mathrm{~cm}$. Changes in root growth intensity were determined by graphing the curve that represented the accumulated number of intersections during one year, while the maximum intensity of annual growth was estimated with the value of the maximum slope of the sigmoid equation, adjusted to the graph of the number of accumulated intersections.

Also, digital soil temperature sensors were installed at depths of 25, 50, 75 and $100 \mathrm{~cm}$ (Onset Computer Corporation, HOBO U12-008, Bourne, Massachusetts, USA). Measurements were taken every hour for one year, beginning 1 September 2004. The average daily temperature was used to carry out the calculations. Each temperature series was used to establish, through correlation and in function of the adjustment achieved, the sinusoid equation that describes the values of the temperature in the daily or annual cycle (Equation [1]) (Monteith and Unsworth, 1990).

$$
T(z, t)=T m+A(\mathrm{z}) \operatorname{seno}(w \cdot t)
$$

Where: $T(z, t)$ : value of temperature at depth $z$ at time $t ; T m$ : mean temperature of the cycle at any depth; $A(\mathrm{z})$ : thermal amplitude; $w$ : angular frequency of the oscillation. For daily cycles $w=(2 \pi / 24) \mathrm{h}^{-1}$, and for annual cycles $w=$ $(2 \pi / 365) \mathrm{d}^{-1} ; t$ : time in hours of the day or days of the year.
In this manner, the mean annual temperature of the soil was estimated, as well as thermal amplitude at depths of 25, 50, 75 and $100 \mathrm{~cm}$. Equation [2] represents soil temperature at a depth for determined moment of the day or the year.

$$
T(z, t)=\mathrm{T}^{*}+A(0) \exp (-z / D) \operatorname{seno}(w \cdot t-z / D)
$$

Where: $T(z, t)$ : temperature at depth $z$ and time $t ; T^{*}$ : mean temperature of the surface; $A(0)$ : thermal amplitude at the surface; $D:\left(2 \mathrm{k}^{\prime} / w\right)^{0.5}$ damping depth, where $\mathrm{k}^{\prime}$ is soil thermal diffusivity; $w$ : angular frequency of the oscillation. For daily cycles $w=(2 \pi / 24) \mathrm{h}^{-1}$, and for annual cycles $w=(2 \pi / 365) \mathrm{d}^{-1}$; and $t$ : time in hours of the day or in days of the year.

From the Equations [1] and [2] the amplitude of the sinusoid that represents the change of temperature in the soil at a depth $z$ can be expressed as:

$$
A(\mathrm{z})=A(0) \exp (-z / D)
$$

Where: $A(z)$ : thermal amplitude at depth $z ; A(0)$ : thermal amplitude at the surface; and $D:\left(2 \mathrm{k}^{\prime} / w\right)^{0.5}$ damping depth, where $\mathrm{k}^{\prime}$ is soil thermal diffusivity.

To estimate the value of $D$ in each soil, four annual thermal amplitudes (one for each depth) were calculated for each soil and only the pair that presented the highest determination coefficients was used in the sinusoidal adjustment. A system of Equations [4] was then established, using Equation [3], where the unknown is the term $D$ or damping depth, which is the depth where the value of thermal amplitude of the surface is reduced by a factor of $\mathrm{e}^{-1}$.

$$
\begin{aligned}
& A\left(\mathrm{z}_{1}\right)=A\left(\mathrm{z}_{2}\right) / \exp \left(-\mathrm{z}_{2} / D\right) \exp \left(-\mathrm{z}_{1} / D\right) \\
& A\left(\mathrm{z}_{2}\right)=A\left(\mathrm{z}_{1}\right) / \exp \left(-\mathrm{z}_{1} / D\right) \exp \left(-\mathrm{z}_{2} / D\right)
\end{aligned}
$$

Where, $A\left(\mathrm{z}_{1}\right)$ and $A\left(\mathrm{z}_{2}\right)$ are the two thermal amplitudes obtained from the adjusted sinusoidal equations with the highest determination coefficient on each soil.

The value of thermal diffusivity in each soil was

Table 1. Geographic location of rhizotrons and soil temperature sensors in vineyards in the Copiapó and Huasco Valleys, Atacama Region, Chile.

\begin{tabular}{lcccc}
\hline & \multicolumn{2}{c}{ Geographic coordinates } & & Altitude \\
\cline { 2 - 3 } Vineyard & South latitude & West longitude & & (m.a.s.l.) \\
\hline El Rosario & $28^{\circ} 45^{\prime} 11.6^{\prime \prime}$ & $70^{\circ} 28^{\prime} 18.0^{\prime \prime}$ & & 985 \\
Santa Cecilia & $27^{\circ} 59^{\prime} 27.9^{\prime \prime}$ & $70^{\circ} 00^{\prime} 38.4^{\prime \prime}$ & & 1223 \\
El Tabaco & $28^{\circ} 47^{\prime} 50.4^{\prime \prime}$ & $70^{\circ} 27^{\prime} 47.6^{\prime \prime}$ & & 973 \\
Altar de la Virgen & $27^{\circ} 59^{\prime} 48.8^{\prime \prime}$ & $69^{\circ} 58^{\prime} 43.5^{\prime \prime}$ & & 1182 \\
\hline
\end{tabular}

m.a.s.l.: meters above sea level. 
obtained by clearing Equation [5] term $k$ ' or thermal diffusivity, defined in Equation [2].

$$
k^{\prime}=D^{2} w / 2
$$

Where: $k^{\prime}$ is soil thermal diffusivity; $D$ is damping depth; and $w$ : angular frequency of the oscillation. For daily cycles $w=(2 \pi / 24) \mathrm{h}^{-1}$ and for annual cycles $w=$ $(2 \pi / 365) \mathrm{d}^{-1}$.

\section{Statistical analysis}

The thermal soil variables were adjusted through regression to Equation [1], and the variable of root growth was adjusted in function of time, to a sigmoid through regression analysis. Statistical analysis was done with the statistical computer program SigmaPlot 10.0 (Systat Software, San Jose, California, USA).

\section{RESULTS AND DISCUSSION}

The thermal dynamic of the soils presented a sinusoidal pattern, characteristic of heating and cooling of soil for an annual cycle. Figure 1 presents the average of monthly mean temperatures of four vineyards, registered at four soil depths. From September 2004 the soils presented a homogenous increase in monthly mean temperature throughout the soil profile, reaching a maximum of $21.6^{\circ} \mathrm{C}$ in February 2005. Once soil cooling started at the beginning of March 2005, an inversion in the thermal profiles was observed until July, when the lowest temperature in the soil profile was reached, $14.7{ }^{\circ} \mathrm{C}$. Between the months of July and August, the increase in the soil surface temperature was higher than at greater depths, with a homogenous thermal profile being observed in August at a mean temperature of $16^{\circ} \mathrm{C}$. Table 2 presents the mean annual temperature and the annual thermal amplitude for four vineyards. The values and the slight variation in annual mean temperature among the sites represents the thermal condition to which soils are exposed in the Copiapó and Huasco Valleys.

By means of adjustments to sinusoidal models, changes of temperature at depths in an annual cycle were represented, obtaining the values of mean temperature and the thermal amplitude of the adjusted sinusoids. As

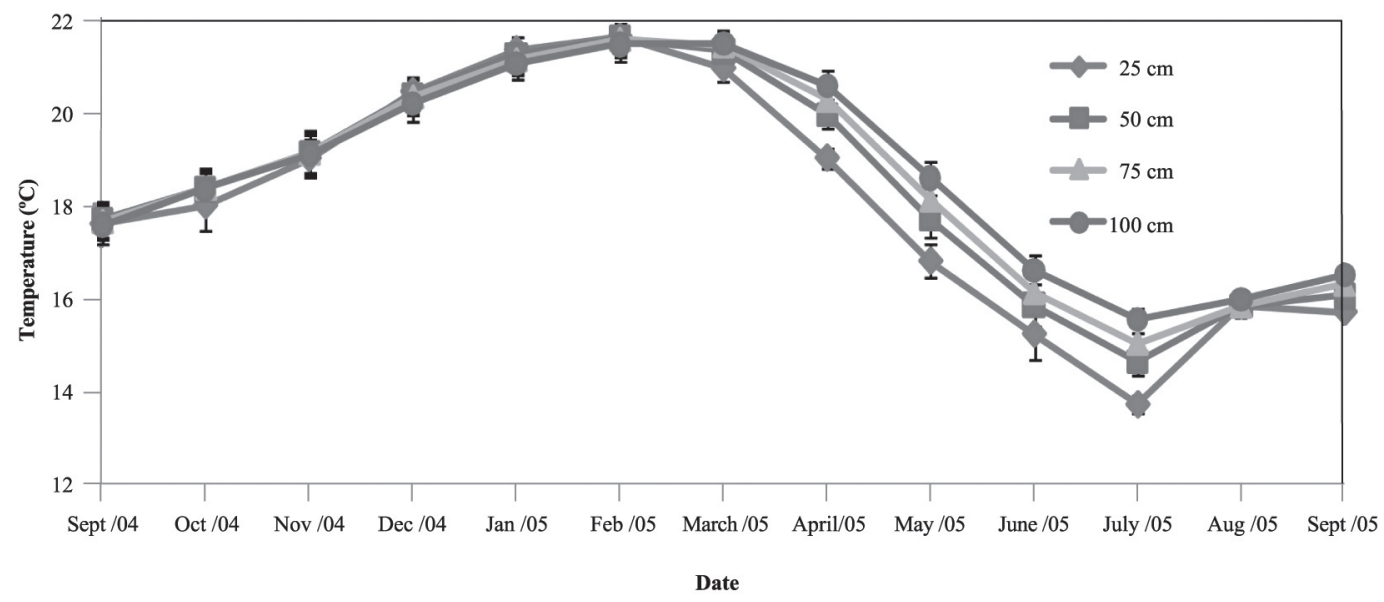

Figure 1. Average monthly temperature at four soil depths in the Copiapó and Huasco Valleys, Atacama Region. Average of four soils. Symbol represents standard error.

Table 2. Average annual temperature and annual thermal amplitude of four soils in the Copiapó and Huasco Valleys, Atacama Region, Chile. Data from September 2004 to September 2005.

\begin{tabular}{|c|c|c|c|c|c|c|c|c|}
\hline \multirow[b]{3}{*}{ Temperature sensor located at: } & \multicolumn{4}{|c|}{ Mean annual temperature } & \multicolumn{4}{|c|}{ Annual thermal amplitude } \\
\hline & \multicolumn{4}{|c|}{ Depth (cm) } & \multicolumn{4}{|c|}{ Depth $(\mathrm{cm})$} \\
\hline & 25 & 50 & 75 & 100 & 25 & 50 & 75 & 100 \\
\hline El Rosario & 20.1 & 20.4 & 20.5 & 20.4 & 3.2 & 3.4 & 3.1 & 3.1 \\
\hline Santa Cecilia & 19.3 & 19.6 & 19.6 & 19.6 & 5.2 & 4.0 & 3.6 & 3.2 \\
\hline El Tabaco & 18.1 & 18.3 & 18.3 & 18.4 & 5.4 & 4.2 & 4.0 & 3.8 \\
\hline Altar de la Virgen & 17.6 & 17.8 & 18.0 & 18.1 & 5.6 & 4.6 & 4.2 & 3.6 \\
\hline
\end{tabular}




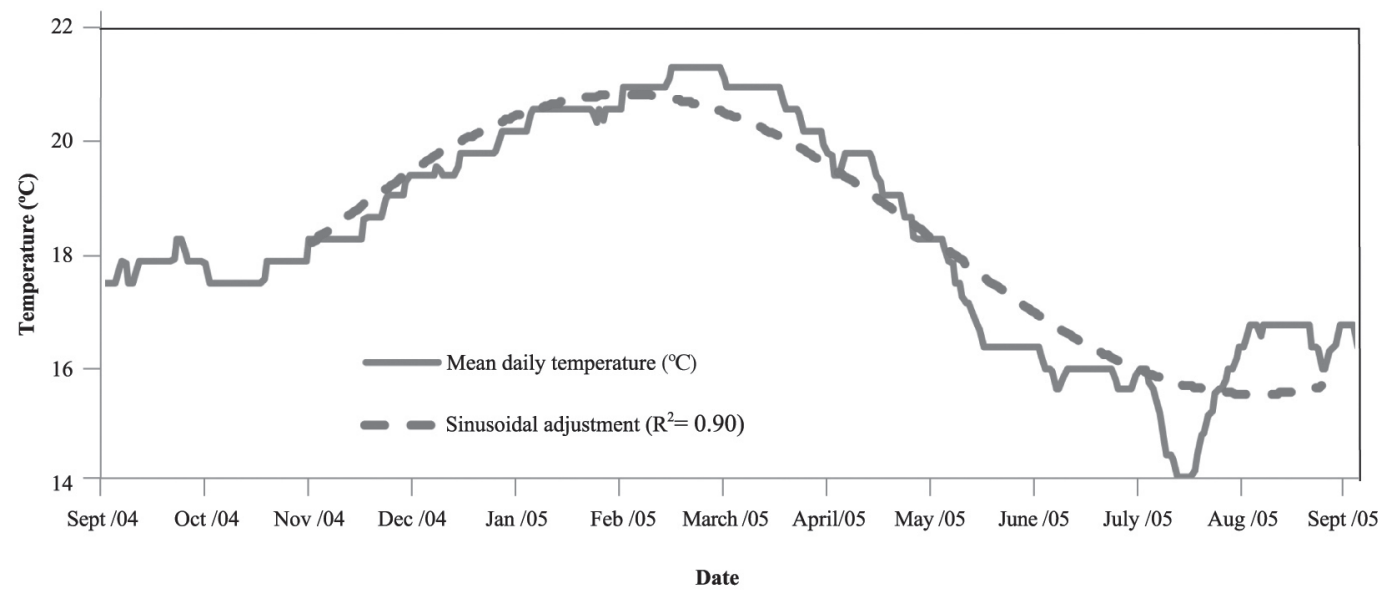

Figure 2. Average daily temperature at a soil depth of $100 \mathrm{~cm}$ and adjusted sinusoidal model. Thermal data obtained from the thermal sensor located at Altar de la Virgen, Copiapó Valley, Atacama Region, Chile.

Table 3. Coefficients of determination of adjusted sinusoidal soil temperature models and time range used. Values from four soil depths (cm) of four soils in the Copiapó and Huasco Valleys, Atacama Region, Chile.

\begin{tabular}{lccccc}
\hline \multirow{2}{*}{$\begin{array}{l}\text { Temperature } \\
\text { sensor located }\end{array}$} & \multicolumn{3}{c}{$\begin{array}{c}\text { Coefficients of determination of the adjusted sinusoidal } \\
\text { at: }\end{array}$} & \multicolumn{3}{c}{\begin{tabular}{c} 
models at four soil depths \\
\cline { 2 - 5 }
\end{tabular}} & $\mathbf{2 5}$ & $\mathbf{5 0}$ & $\mathbf{7 5}$ & $\mathbf{1 0 0}$ & $\begin{array}{c}\text { Time range used for the } \\
\text { sinusoidal adjustment }\end{array}$ \\
\hline El Rosario & 0.87 & 0.92 & 0.94 & 0.83 & $01 / 11 / 2004$ to $19 / 10 / 2005$ \\
Santa Cecilia & 0.89 & 0.92 & 0.93 & 0.96 & $02 / 10 / 2004$ to $28 / 08 / 2005$ \\
El Tabaco & 0.87 & 0.93 & 0.92 & 0.90 & $15 / 11 / 2004$ to $31 / 08 / 2005$ \\
Altar de la Virgen & 0.85 & 0.90 & 0.90 & 0.90 & $30 / 10 / 2004$ to $19 / 10 / 2005$ \\
\hline
\end{tabular}

an example, Figure 2 presents the sinusoid and the degree of adjustment obtained in the soil of the vineyard Altar de la Virgen at a depth of $100 \mathrm{~cm}$. The degree of adjustment achieved by the sinusoidal models and timer period used in each soil is presented in Table 3 .

Thermal diffusivity is defined by the coefficient between the thermal conductivity of the soil and volumetric thermal capacity, while the relation between thermal diffusivity and the water content in large measure determine thermal kinetics of irrigated soils. Monteith and Unsworth (1990) propose that very dry soils rapidly increase their thermal conductivity when a small quantity of water is added, implying a major increase in thermal conductivity above the increase in specific volumetric heat. As that the water content in the soil increases, there is less change in thermal conductivity because vapor diffusion decreases as the pores are saturated with water. Similarly, the change in specific volumetric heat began to be greater than the change in soil conductivity, resulting in a decrease in thermal diffusivity. In etween these two regimes (dry and wet), soil thermal diffusivity presents its maximum value. Wieringa and Lomas (2001) indicate that soil thermal diffusivity is on the order of $10^{-6} \mathrm{~m}^{2} \mathrm{~s}^{-1}$ for the mineral constituents of the soil and 3 to $8 \times 10^{-7} \mathrm{~m}^{2} \mathrm{~s}^{-1}$ for soils. The values of thermal diffusivity were estimated in soil depth ranges below $50 \mathrm{~cm}$ (Table 4), resulting in values on the order of $10^{-6} \mathrm{~m}^{2} \mathrm{~s}^{-1}$. Also, values for the damping depth were estimated between 3 to $9 \mathrm{~m}$.

In order to represent root system growth of the grapevine cv. Thompson Seedless at different depths, the average of weekly intersections was divided by the highest value observed during the year, obtaining the distribution of annual growth in relative terms. The roots grew throughout the year, presenting minimal values in July and reaching similar growth levels during flowering and harvest (Figure 3). To estimate the intensity of annual growth of root systems, graphs were made of the number of accumulated intersections during a year beginning 1 September 2004. Subsequently, by means of adjustment to a sigmoid model, the equation that represents the number of accumulated intersections in function of time was obtained. The maximum intensity of annual growth 
Table 4. Soil thermal diffusivity, soil depth range used and damping depth of four soils in the Copiapó and Huasco Valleys, Atacama Region, Chile.

\begin{tabular}{lccc}
$\begin{array}{l}\text { Temperature } \\
\text { sensor located } \\
\text { at: }\end{array}$ & $\begin{array}{c}\text { Soil thermal } \\
\text { diffusivity }\end{array}$ & $\begin{array}{c}\text { Depth range used } \\
\text { for the } \\
\text { estimation }\end{array}$ & Damping depth \\
\hline & $10^{-6} \mathrm{~m}^{2} \mathrm{~s}^{-1}$ & $50-75$ & $\mathrm{~cm}$ \\
El Rosario & 8.9 & $75-100$ & 547 \\
Santa Cecilia & 2.5 & $50-75$ & 305 \\
El Tabaco & 5.5 & $75-100$ & 335 \\
Altar de la Virgen & 1.7 & & 345 \\
\hline
\end{tabular}

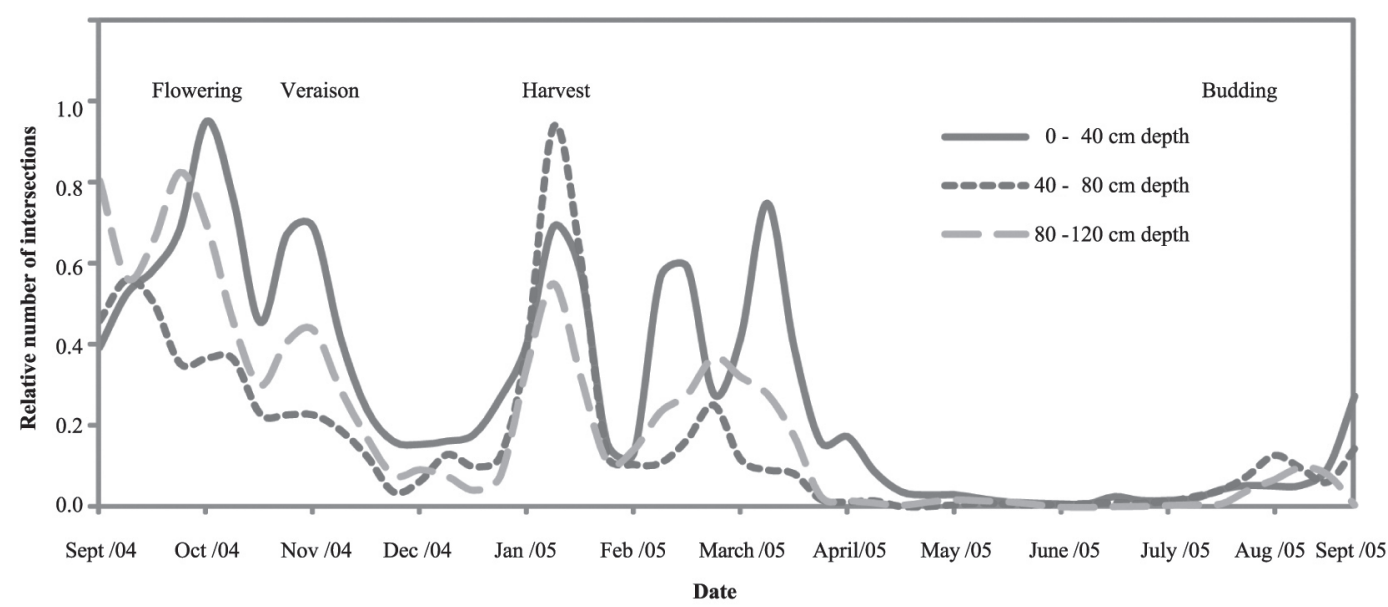

Figure 3. Relative number of root intersections with the grid lines at three soil depth ranges. Average of four rhizotrons installed in 'Thompson Seedless' grapevines at the Copiapó and Huasco Valleys, Atacama Region, Chile.

corresponded to the value of the maximum slope for the adjusted sinusoid model. For example, Figure 4 shows the graph of the accumulated number of intersections and the adjusted sigmoid model for the Altar de la Virgen rhizotron for the range of 0 to $40 \mathrm{~cm}$ of soil depth. The maximum

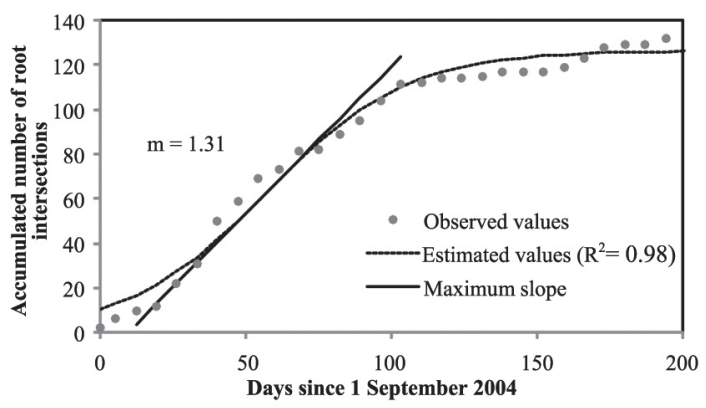

Figure 4. Accumulated number of root intersections. Observed and estimated values, and maximum slope (m) of rhizotron Altar de la Virgen (soil depth range of 0 to $40 \mathrm{~cm}$ ), installed in 'Thompson Seedless' grapevines in the Copiapó Valley, Atacama Region, Chile. intensity of annual growth presented by the root systems and their distribution in three depth ranges are presented in Table 5. The degree of adjustment by sigmoid models and the period of time used are presented in Table 6 .

The root system of the grapevine is characterized by a high level of exploration and low root density (Nagarajah, 1987; Morano and Kliewer, 1994). Silva et al. (1991) estimated that the majority of 'Thompson Seedless' roots are found at depths of 40 to $60 \mathrm{~cm}$. As well, it has been reported that grapevine roots have the potential to grow to depths of $600 \mathrm{~cm}$ (Seguin, 1972). The differences between the maximum and minimum intensities of annual root system growth (Table 5) were on the order of five times when considered at the depth range of 0 to $120 \mathrm{~cm}$. As well, particular patterns of root growth were observed in each rhizotron during the season.

Ibacache and Lobato (1995) determined a significant linear relationship between the intensity of root growth of the grapevine cv. Gold and soil temperature at depths of 20 and $50 \mathrm{~cm}$. The present study determined that root growth in the spring of 2005 started at the beginning of July, characterized by an increase in the number of 
Table 5. Maximum annual root growth rate distribution of four 'Thompson Seedless' grapevines within three soil depth (cm) ranges and soil profile, at the Copiapó and Huasco Valleys, Atacama Region, Chile.

\begin{tabular}{|c|c|c|c|c|}
\hline \multirow[b]{3}{*}{ Rhizotron located at: } & \multicolumn{4}{|c|}{ Maximum intensity of root system growth in three ranges of soil depth and profile } \\
\hline & \multicolumn{4}{|c|}{ (Number of root intersections $d^{-1}$ ) } \\
\hline & $0-40$ & $40-80$ & $80-120$ & $0-120$ \\
\hline El Rosario & 3.0 & 4.6 & 3.7 & 10.7 \\
\hline Santa Cecilia & 1.5 & 1.3 & 1.0 & 3.1 \\
\hline El Tabaco & 3.7 & 3.3 & 4.6 & 9.7 \\
\hline Altar de la Virgen & 1.3 & 0.8 & 0.2 & 2.1 \\
\hline
\end{tabular}

Table 6. Coefficient of determination of sigmoid models adjusted to the accumulated number of intersected roots and time range used. Values of three soil depth $(\mathrm{cm})$ ranges and soil profile of four root systems of 'Thompson Seedless' grapevine in the Copiapó and Huasco Valleys, Atacama Region, Chile.

\begin{tabular}{|c|c|c|c|c|c|}
\hline \multirow[b]{2}{*}{ Rhizotron located at: } & \multicolumn{4}{|c|}{$\begin{array}{l}\text { Determination coefficient of sigmoid models adjusted } \\
\text { to the accumulated number of root intersections }\end{array}$} & \multirow{2}{*}{$\begin{array}{l}\text { Time range used in the } \\
\text { sigmoid adjustment }\end{array}$} \\
\hline & $0-40$ & $40-80$ & $80-120$ & 0 - 120 & \\
\hline El Rosario & 0.97 & 0.95 & 0.95 & 0.97 & $02 / 09 / 2004$ to $28 / 03 / 2005$ \\
\hline El Tabaco & 0.99 & 0.98 & 0.96 & 0.99 & $02 / 09 / 2004$ to $24 / 11 / 2004$ \\
\hline Santa Cecilia & 0.98 & 0.96 & 0.96 & 0.98 & $07 / 09 / 2004$ to $12 / 07 / 2005$ \\
\hline Altar de la Virgen & 0.98 & 0.98 & 0.99 & 0.98 & $01 / 09 / 2004$ to $28 / 03 / 2005$ \\
\hline
\end{tabular}

intersections (Figure 3), coincided with an increase in soil temperature (Figure 1). While the optimal temperature for grapevine root growth has been described as 25 to 30 ${ }^{\circ} \mathrm{C}$ (Kliewer, 1975), in this study the maximum intensity of annual root growth was not related to mean annual temperature, but rather to soil thermal diffusivity through a lineal model (Figure 5). The results obtained indicate that the soils present apt temperatures for the development of the root system throughout the year, estimating that the soils of the Copiapó and Huasco Valleys, with high thermal diffusivities, present favorable thermal conditions for the development of grapevine root systems.

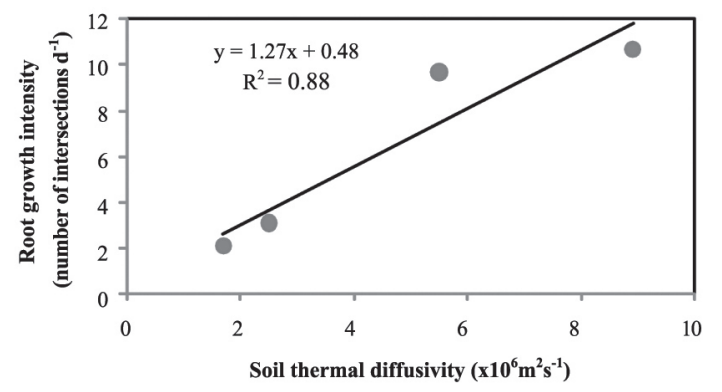

Figure 5. Annual root growth rate of 'Thompson Seedless' grapevines, according to soil thermal diffusivity. Values of four rhizotrons in the Copiapó and Huasco Valleys, Atacama Region, Chile.

\section{CONCLUSIONS}

In accordance with the conditions under which the study was carried out, it was concluded that in the highlands of the Copiapó and Huasco Valleys (desert highland climate) cv. Thompson Seedless presents continuous root growth at different soil depths, increasing in intensity at flowering and harvest and decreasing to minimal levels in July.

The maximum intensity of annual root growth of this cultivar is highly variable, as is the depth of root distribution.

The average annual soil temperature was not related to the maximum intensity of annual root growth of 'Thompson Seedless'.

Variation in annual root growth varied correlated with soil thermal diffusivity.

\section{ACKNOWLEDGEMENTS}

The authors are grateful for the support provided by table grape producers from the Copiapó and Huasco Valleys, Atacama Region, and in particular by Fernando Prohens E. As well, they are grateful for the support of the Agricultural Innovation Fund (FIA), project FIA-PIC-2003-1-A-037. 


\section{RESUMEN}

Relación entre el crecimiento radical de vid 'Thompson Seedless' y la temperatura del suelo. Con el objetivo de caracterizar el crecimiento del sistema radical de la vid (Vitis vinifera L.) cv. Thompson Seedless y su relación con la temperatura del suelo, durante la temporada 20042005 se llevó a cabo un estudio en parronales ubicados en los valles de Copiapó y Huasco. Se instalaron cuatro cámaras de observación de raíces o rizotrones en plantas homogéneas, en plena producción, pie franco, sanas, y ubicadas en diferentes localidades de la región. Las mediciones del crecimiento de las raíces se efectuaron semanalmente, desde septiembre de 2004 hasta completar 1 año, estimándose la intensidad de crecimiento radical anual y su distribución en los rangos de 0 a 40, 40 a 80 y 80 a $120 \mathrm{~cm}$ de profundidad. Adicionalmente, se instalaron sensores de temperatura a 25, 50, 75 y 100 $\mathrm{cm}$ de profundidad y se registró la temperatura cada $1 \mathrm{~h}$. Con los valores de temperatura media anual y amplitud térmica anual se calculó la difusividad térmica de los suelos. Se observó crecimiento radical durante todo el año presentando menor intensidad en el mes de julio (invierno). Las raíces mostraron diferentes patrones en la distribución de la intensidad de crecimiento en los tres rangos de profundidad, con variaciones entre los sitios de hasta cinco veces en la máxima intensidad de crecimiento anual. Suelos con difusividades térmicas altas presentaron ambientes favorables para el crecimiento de raíces.

Palabras clave: raíces, difusividad térmica, uva de mesa.

\section{LITERATURE CITED}

Ibacache, A., y A. Lobato. 1995. Períodos de crecimiento de raíces en vid. Revista Frutícola (Chile) 16:23-26.

Kliewer, W.M. 1975. Effect of root temperature on budbreak, shoot growth, and fruit-set of "Cabernet Sauvignon" grapevine. Am. J. Enol. Vitic. 26:82-89.

McArtney, S.J., and D.C. Ferree. 1999. Shading effects on dry matter partitioning, remobilization of stored reserves and early season vegetative development of grapevines in the year after treatment. J. Amer. Soc. Hort. Sci. 124:591-597.

McMichael, L., and J.J. Burke. 1998. Soil temperature and root growth. HortScience 33:947-950.

Monteith, J.L., and M.H. Unsworth. 1990. Principles of environmental physics. 291 p. $2^{\text {nd }}$ ed. E. Arnold, London, England.
Morano, L., and W.M. Kliewer. 1994. Root distribution of three grapevine rootstock grafted to Cabernet Sauvignon grown on a very gravelly clay loam soil in Oakville, California. Am. J. Enol. Vitic. 45:345-348.

Nagarajah, S. 1987. Effects of soil texture on the rooting patterns of Thompson Seedless vines on own roots and on Ramsey rootstock in irrigated vineyards. Am. J. Enol. Vitic. 38:54-59.

Novoa, R., S. Villaseca, P. Del Canto, J.L. Rouanet, C. Sierra, y A. Del Pozo. 1989. Mapa agroclimático de Chile. 221 p. Instituto de Investigaciones Agropecuarias INIA, Santiago. Chile.

Psarras, G., I.A. Merwin, A.N. Lakso, and J.A. Ray. 2000. Root growth phenology, root longevity, and rhizosphere respiration of field grown "Mutsu" apple trees on "Mailing 9" rootstock. J. Amer. Soc. Hort. Sci. 125:596-602.

Ruiz, S. 2000. Dinámica nutricional en cinco parrones de diferente productividad del Valle Central regado de Chile. Agric. Téc. (Chile) 60:379-398.

Seguin, M.G. 1972. Répartition dans l'espace du système radiculaire de la vigne. C.R. Acad. Sci. 274:21782180.

Silva, H., R. Honorato, y C. Bonomelli. 1991. Crecimiento radical y desarrollo de la vid variedad Thompson Seedless. Revista ACONEX (Chile) 34:14-21.

Terence, R.B., R.M. Dunst, and P. Joy. 2002. Seasonal dry matter, starch, and nutrient distribution in "Concord" grapevine roots. HortScience 37:313-316.

van Noordwijk, M., J. Floris, and A. Jager. 1985. Sampling schemes for estimating root density distribution in cropped fields. Neth. J. Agric. Sci. 33:241-262.

Wieringa, J., and J.Lomas. 2001. Lecture notes for training agricultural meteorological personnel. Education and Training Programme. $2^{\text {nd }} e d . W M O \mathrm{~N}^{\circ} 551.196 \mathrm{p}$. World Meteorological Organization (WMO), Geneva, Switzerland.

Woodham, R.C., and D. McE. Alexander. 1966. The effect of root temperature on development of small fruiting Sultana vines. Vitis 5:345-350. 